\title{
Preservation of Shellfish Undulate Venus (Paphia undulata) by Canning with Different Treatments
}

\author{
Nadia A. Abd-El-Aziz \\ Meat and Fish Technology Research Department, Food Technology Research Institute, Agriculture, Research Center, Alexandria, \\ Egypt \\ Email: dr.nadiaahmed@yahoo.com
}

How to cite this paper: Abd-El-Aziz, N.A. (2021) Preservation of Shellfish Undulate Venus (Paphia undulata) by Canning with Different Treatments. Food and Nutrition Sciences, 12, 859-873.

https://doi.org/10.4236/fns.2021.129064

Received: August 11, 2021

Accepted: September 4, 2021

Published: September 7, 2021

Copyright (๑) 2021 by author(s) and Scientific Research Publishing Inc. This work is licensed under the Creative Commons Attribution International License (CC BY 4.0).

http://creativecommons.org/licenses/by/4.0/

\begin{abstract}
Our study investigated preservation Undulate venus (Paphia undulata) by canning via three treatments that are canned raw, canned smoked and canned cooked as a healthy product with high nutritional value. Results reported that edible meat of Paphia undulata was free from $\mathrm{Cu}, \mathrm{Pb}$ and $\mathrm{Cd}$ as a result of washing process. There was significantly $(\mathrm{p}<0.05)$ higher in moisture content of canned raw compared with other tow treatments of canned smoked and canned cooked of Paphia undulata, and there was significantly reduction of protein content $(\mathrm{p}<0.05)$ in tow treatments of canned smoked and canned cooked compared with the canned raw. Significant different $(\mathrm{p}<0.05)$ in fat content was canned raw $<$ canned smoked $<$ canned cooked. On the other side, the three treatments of canned shellfish Paphia undulata had significant difference $(\mathrm{p}<0.05)$ in content of ash and carbohydrates content. Canned smoked of shellfish Paphia undulata showed the lowest value of $\mathrm{pH}$. All treatments of canned shellfish Paphia undulata were rich in minerals where canned raw treatment was higher in $\mathrm{Ca}, \mathrm{Fe}, \mathrm{Zn}, \mathrm{Mg}$, and $\mathrm{Mn}$. While canned smoked had minerals content lower than canned raw. Lightness $\left(L^{\star}\right)$ had slightly difference between all treatments of canned shellfish Paphia undulata. Reduction on lightness and redness was noticed at the same time in all treatments of canned shellfish Paphia undulate, canned raw had the highest value of lightness $\left(\mathrm{L}^{\star}\right)$, and redness $\left(\mathrm{a}^{*}\right)$. Canned smoked had the highest value of hardness followed by canned raw then canned cook. Slightly significant difference $(\mathrm{p}<0.05)$ was noticed between three treatments in sensory properties, data showed that all panelists preferred canned cooked than raw canned and canned smoked, degree of canned cooked was excellent.
\end{abstract}

\section{Keywords}

Shellfish, Paphia undulata, Canning, Smoking 


\section{Introduction}

Shellfish are animals that dwell in water and have a shell or shell-like exterior. We can divide shellfish into two groups: first are crustaceans and second are mollusks. Crustaceans are invertebrates with segmented bodies, protected by hard shells made of chitin, and include shrimp, lobster, crayfish, crab, and krill. Mollusks are invertebrates with soft bodies, divided into foot and visceral section. Clams, scallops, oysters, and mussels are examples of mollusks. Shellfish are rich in protein, and healthy fats, contain high amounts of certain micronutrients, including vitamins and minerals such as iron, zinc, magnesium., inorganic phosphate, sodium, potassium, selenium, iodine, and also other nutrients. Regularly eating shellfish may increase immunity, and promote brain and heart health [1] [2].

Shellfish to be eaten raw are very high risk products, some of these hazards are specific for shellfish and are related to the environment where the animals are captured, and may contaminate with pathogens bacteria. The consumption of shellfish (such as crab, shrimp, and krill, etc) as an important nutritional source is increasing globally [3]. Nevertheless, shelf-life of shellfish is normally limited, mainly associated with the microbial growth and quality deterioration over the whole supply chain [4]

Undulate venus (Paphia undulata) is an abundant marine shellfish resource, which widely cultured and it sold at a low price and high economic benefit. $\mathrm{Pa}$ phia undulata is a good source of protein, consisting of approximately $68.77 \%$ crude protein "dry weight basis" [5]. Paphia undulata was content with high proteins especially essential amino acids which consider an essential source of nutrients for many people, especially in developing countries [6].

Contaminate shellfish with toxic heavy metals, such as mercury $(\mathrm{Hg})$, cadmium (Cd), and lead can cause adverse health effects [7]. Processed shellfish products must get rid of pathogenic organisms but if the processing treatment is not adequate to eliminate them, many cases of botulism are associated with this product which subjected to inadequate thermal treatment [8].

Shellfish meat is frequently eaten raw in some European countries. For this purpose, the whole live oyster is subjected to cleansing process for $36 \mathrm{~h}$ in recirculated seawater and is treated with ultraviolet light or for $48 \mathrm{~h}$ in chlorinated seawater in static tanks with a change of water after 24 [9].

Canning is an important, safe method of food preservation when practiced properly. The canning process includes placing foods in jars and heating them to a temperature that destroys microorganisms that could be a health hazard or cause the food to spoil. Also, canning inactivates enzymes that could cause the food to spoil. Raw seafood may contain microorganisms that cause food poisoning. These bacteria are destroyed by heating the seafood before eating. On the other hand, canning provides a shelf life that typically ranges from one to five years [10] [11].

Smoking of meat and meat products is one of the oldest processing methods 
in food preservation. Smoke not only gives special taste, colour and aroma, but also enhances preservation due to the dehydrating, bactericidal and antioxidant properties of smoke [12].

Therefore, this study amied to produce a healthy product with high nutritional value, rich in mineral, free from heavy metals and bacterial hazard by canning Undulate venus (Paphia undulate) with tree treatment to extend its shelf life and preserve the quantities of corruption.

\section{Material and Methods}

\subsection{Material}

Fresh tomato, green pepper, onion, garlic and celery, refined fine iodized common salt, spices blend mixture white, red and black pepper, cumin, paprika, corn oil, tomato sauce, natural smoke concentrate (Meat and Fish Technol. Res. Dept, Agriculture Research Center), fresh shellfish [undulate venus (Paphia undulata)], was obtained from Alexandria fish market, and cans were obtained from a local market, Alexandria city, Egypt. All reagents and chemicals used in this study were an analytical grade

\subsection{Methods}

\subsubsection{Technological Methods}

Preparation of shellfish: Undulate venus (Paphia undulata) was washed and cleaned of mud and dirt by a water, To get the best quality product, raw shellfish (should be alive until use) so we were looked for tightly closed shells. If the shells are gaping open or don't close when we wash them or put them in cold water, we discard the shellfish, the Paphia undulata was subjected to a cleaning process by the method suggested by [13] for clams and mussels. then Paphia undulata soaked in tap water for $8 \mathrm{~h}$ with changing water every one hour, to get rid of heavy metals, then washed to remove mud, drained, steamed at $100^{\circ} \mathrm{C}$ for 10 minutes, cooled at room temperature, during this process the shells open up and shucking becomes easy, and separation edible meat from shellfish the meat was washed well to free it from grit and dirt.

Smoking of Paphia undulate: edible meat of soaked (Paphia undulate) was smoked by liquid smoke solution (natural smoke concentrate: water as $1: 1 \mathrm{v} / \mathrm{v}$ ), since the edible part of (Paphia undulata) was soaked and sprayed by liquid smoke solution each $5 \mathrm{~min}$. The smoking process was carried out in a smoking kiln (AFOS, MK2, Torry mini \& maxi smoker, England) at $70^{\circ} \mathrm{C}$ for $1 \mathrm{hr}$ then the samples were obtained and cooled.

Seafood soup preparation: (Paphia undulata) after washed and soaked in water cooked with ingredients fresh tomato, green pepper, onion, garlic, celery, salt, spices blend mixture white, red and black pepper, cumin, and paprika, at $100^{\circ} \mathrm{C}$ for $15 \mathrm{~min}$.

Canning of Paphia undulate: three treatments of canning shellfish (Paphia undulata) were prepared 1) raw edible meat of Paphia undulata canned in 2\% 
sodium chloride solution with $8 \%$ tomato sauce as filling media(canned raw), 2) smoked edible meat of Paphia undulata canned in 2\% sodium chloride solution as filling media (canned smoked), 3) canned cooked edible meat of Paphia undulata as seafood soup. filling media was soup, (canned cooked), all treatment were blanched in $100 \mathrm{~g}$ and packed with different filling media in lacquered cylinder tin cans of dimensions $(\mathrm{h}=11 \mathrm{~cm}$, diameter $=6.5 \mathrm{~cm})$ considering leave head space. Cans were crimped and sterilized at $121^{\circ} \mathrm{C}$ for $20 \mathrm{~min}$.

\subsubsection{Analytical Method}

1) Physicochemical properties: The colour values, lightness $\left(L^{\star}\right)$, redness $\left(a^{*}\right)$ and yellowness $\left(b^{*}\right)$, of food samples were evaluated using a Hunter Lab Ultra Scan, VIS model, colorimeter (USA). The instrument was standardized during each sample measurement with a black and white tail $\left(\mathrm{L}^{*}=94.1, \mathrm{a}^{*}=1.12\right.$, $\left.b^{*}=1.26\right)$. Mean of five readings of each colour index of Hunter scale $\left(L^{*}, a^{*}, b^{*}\right)$ were recorded [14].

Texture Profile Analysis (TPA) of canned shellfish was performed using TA-XT 2 Texture meter (Texture Pro CT3 V1.2, Brookfield, Middleboro, USA) as described by [15]. Force time deformation curves were obtained during applying a $5 \mathrm{~kg}$ load cell, at a $1 \mathrm{~mm} / \mathrm{s}$ cross head speed. The following texture attributes were calculated hardness.

\section{2) Chemical analysis:}

Proximate composition: Moisture, crude protein, crude fat and ash contents canned shellfish were determined according to [16], while carbohydrates were calculated by difference.

$\mathrm{pH}$ was determined using $\mathrm{pH}$ meter type MVX100 Beckman (USA) at room temperature $\left(22^{\circ} \mathrm{C} \pm 3^{\circ} \mathrm{C}\right)$ as described in [16].

Heavy metals: $\mathrm{Pb}, \mathrm{Cd}$ and $\mathrm{Cu}$ concentration in canned shellfish sample were determined after digestion using ICP-OES according to the method of [17].

Minerals determination: $\mathrm{Ca}, \mathrm{Fe}, \mathrm{Zn}, \mathrm{Mg}$ and $\mathrm{Mn}$ were determined using Inductively Coupled Plasma Atomic Emission Spectroscopy (ICP-OES) according to standard method US EPA Meth d 200.7 and US EPA Method 6010 C.

\subsubsection{Sensory Evaluation}

Colour, texture, taste, odour and overall acceptability of canned shellfish were organoleptically evaluated using 10 trained panelists from, Food Science and Technology Department, Faculty of Agriculture, Alexandria University. They were asked to rate their acceptabilities of canned shellfish products according to nine point scale, ranging from the like extreme 9 to dislike extreme 1 point as described by [18].

\subsubsection{Statistical Analysis}

Data was statistically analyzed using Statistical Package for Social Sciences (SPSS) software version 22. The level of significant difference was determined at $\mathrm{P} \leq 0.05$. Mean \pm Standard Deviation (SD) of mean was used. 


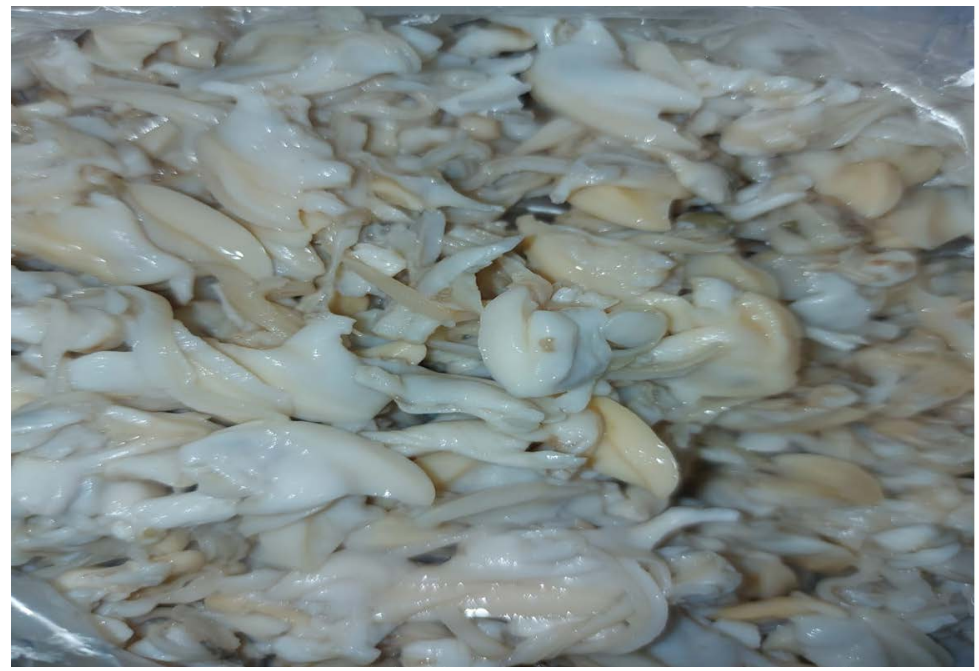

Canned raw

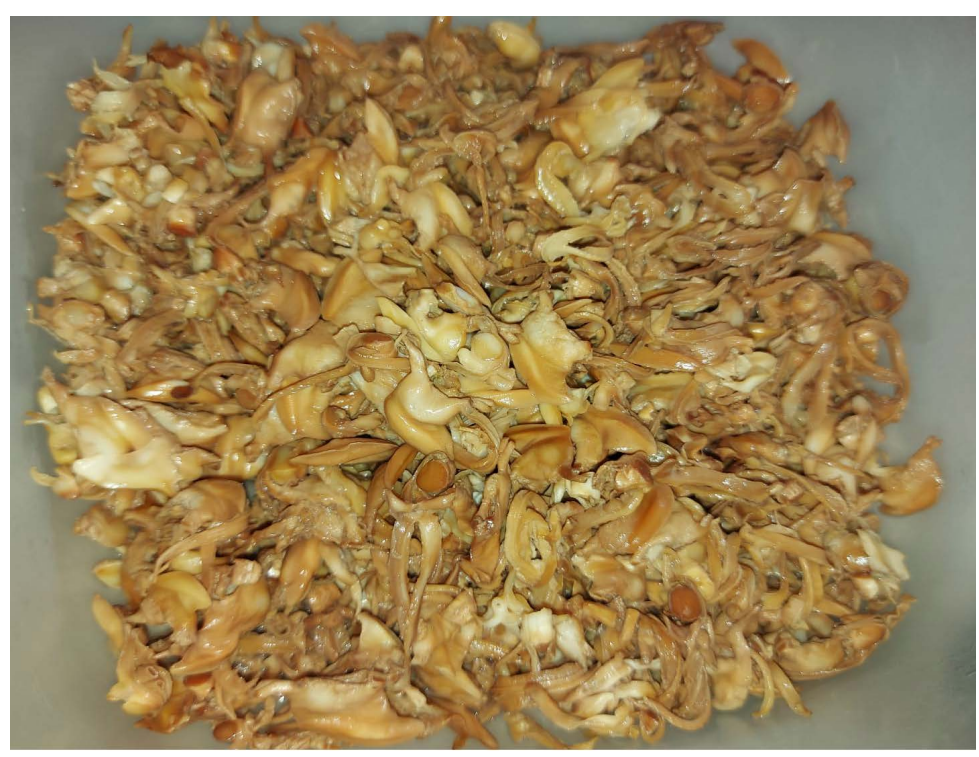

Canned smoked

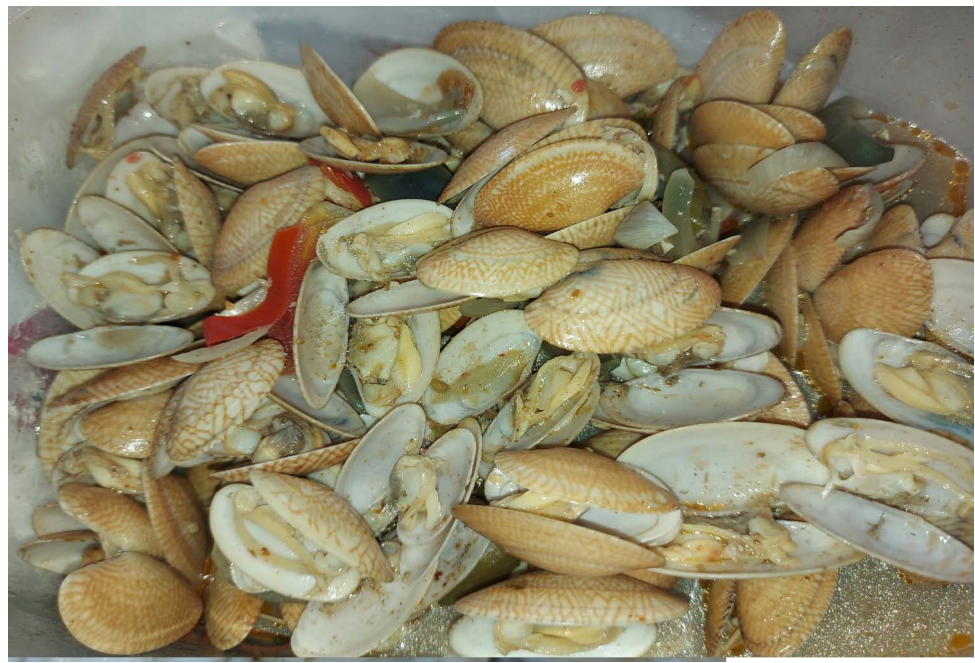

Canned cooked 


\section{Results and Discussion}

\subsection{Chemical Composition}

\subsubsection{Heavy Metals Concentration}

Table 1 showed the concentration of $\mathrm{Cu}, \mathrm{Pb}$ and $\mathrm{Cd}(\mathrm{mg} / \mathrm{kg})$ in Paphia undulata, in fresh shellfish Paphia undulata and after soaking in tap water and washing before canning process. Results reported that edible meat of Paphia undulata were free from $\mathrm{Cu}, \mathrm{Pb}$ and $\mathrm{Cd}$ as a result of washing process that get rid all traces of $\mathrm{Cu}$ which found in edible meat before washing. [19] showed that edible tissues of wild-caught crab, were detected some toxic elements above the standard of food safety. this therefore might pose a threat to human health. [20] reported that soaking oyster meat with epigallocatechin-3-gallate after washing with slightly acidic electrolyzed water could be stored for 13 days with good quality both microbiological and physico-chemical properties under cold storage.

[21] showed that the levels of cadmium in samples of fish and meat products analyzed ranged from 0.77 to $1.04 \mu \mathrm{g} / 100$ (mean: $0.91 \mu \mathrm{g} / 100 \mathrm{~g}$ ), this is below the codex committee on food additives and contaminants [22] draft guideline of 0.5 $\mathrm{mg} \mathrm{Cd} / \mathrm{kg}$. Cadmium may accumulate in the human body and may induce kidney dysfunction, skeletal damage and reproductive deficiencies Lead is known to induce reduced cognitive development and intellectual performance in children and increased blood pressure and cardiovascular disease in adults, [23]. Copper is essential for good health but very high intakes can cause health problems such as liver and kidney damage [24]. The upper tolerable intake level of copper for children ( 1 - 3 years old) and males/females (19- 70 years old) is 1 and $10 \mathrm{mg} / \mathrm{d}$, respectively [25].

\subsubsection{Proximate Composition}

Table 2 showed that moisture content of shellfish canned were ranged form $71.46 \%$ to $74.33 \%$ It was significantly higher in canned raw than other tow treatment canned cooked, and canned smoked, was the lowest in moisture content, this attributed to different treatment before canning. canned raw was highest moisture content because it was not exposed to smoking and cooking process which due to reduction of moisture value [26] reported that smoking caused reduction in moisture content due to muscle dehydration. [27] showed that the proximate compositions of cooked meats crab were not much different according to the species, which contained $76.9 \%-80.7 \%$ moisture.

On dry weight basis, the three treatments of canned shellfish (Paphia undulata) were considered rich in protein $73.67 \%, 68.64 \%$, and $60.63 \%$ in canned raw, canned smoked and canned cooked respectively, There was significantly reduction of protein content $(\mathrm{p}<0.05)$ in smoked and cooked treatments, this mean that shellfish (Paphia undulata) a good source of protein and these reduction in protein content attributed to heat effect in smoking and cooking process. In addition proteins can react directly with reactive oxygen formed during drying and smoking processes, whereas heat due to degradation of protein in canned cook comparison with the canned raw. Canned smoked shellfish (Paphia undulata) 
Table 1. Heavy metals concentration $(\mathrm{mg} / \mathrm{kg})$ in edible meat of (Paphia undulata) as row material before canning.

\begin{tabular}{|c|c|c|c|c|}
\hline \multirow[b]{2}{*}{ Heavy metals } & \multicolumn{2}{|c|}{ Concentration $(\mathrm{mg} / \mathrm{kg}) \mathrm{Wwb}^{*}$} & \multirow{2}{*}{$\begin{array}{c}\text { Maximum } \\
\text { Permissible } \\
\text { level (mg/kg) }\end{array}$} & \multirow{2}{*}{$\begin{array}{l}\text { Recommended } \\
\text { by }\end{array}$} \\
\hline & Zero time & $\begin{array}{l}\text { After washing } \\
\text { and soaking }\end{array}$ & & \\
\hline Copper $(\mathrm{Cu})$ & 6.16 & N.D $D^{* * *}$ & 30.0 & FAO (1992) \\
\hline Lead $(\mathrm{Pb})$ & N.D & N.D & $\begin{array}{l}2.0 \\
0.1\end{array}$ & $\begin{array}{c}\text { FAD (2001) } \\
(\text { EOSQC, 1993) }\end{array}$ \\
\hline Cadmium (Cd) & N.D & N.D & $\begin{array}{l}3.0 \\
1.0\end{array}$ & $\begin{array}{c}\text { FAO }(1992) \\
\operatorname{EOSQC~}(1993)^{\star *}\end{array}$ \\
\hline
\end{tabular}

* Wet weight basis; ${ }^{* *}$ Egyptian Organization for Standardization and Quality Control (EOSQC, 1993).

Table 2. Proximate composition, and $\mathrm{pH}$ of canning (Paphia undulata).

\begin{tabular}{cccc}
\hline Component (\%) & Canned raw & Canned smoked & Canned cooked \\
\hline Moisture & $74.33 \pm 0.56^{\mathrm{a}}$ & $71.46 \pm 0.30^{\mathrm{c}}$ & $72.29 \pm 0.16^{\mathrm{b}}$ \\
Crude protein & $73.67 \pm 0.11^{\mathrm{a}}$ & $68.64 \pm 0.16^{\mathrm{b}}$ & $60.63 \pm 0.15^{\mathrm{c}}$ \\
Crud fat & $8.49 \pm 0.34^{\mathrm{c}}$ & $9.23 \pm 0.16^{\mathrm{b}}$ & $14.96 \pm 0.14^{\mathrm{a}}$ \\
Ash & $8.68 \pm 0.22^{\mathrm{c}}$ & $12.39 \pm 0.10^{\mathrm{b}}$ & $19.59 \pm 0.22^{\mathrm{a}}$ \\
Carbohydrate & $9.16 \pm 0.06^{\mathrm{b}}$ & $9.74 \pm 0.22^{\mathrm{a}}$ & $4.82 \pm 0.18^{\mathrm{c}}$ \\
Total caloric value (kcal/100 g) & 407.73 & 396.66 & 397.12 \\
Percentage of protein calories to total cal. & 18.07 & 17.34 & 15.26 \\
pH value & $5.03 \pm 0.07^{\mathrm{b}}$ & $4.53 \pm 0.01^{\mathrm{c}}$ & $5.47 \pm 0.02^{\mathrm{a}}$ \\
\hline
\end{tabular}

Data as mean $\pm \mathrm{SD}$. Means in the same column sharing the same letters are not significantly different at $\mathrm{P} \leq$ 0.05 level.

was higher protein content than canned cooked shellfish (Paphia undulata) as a results of high temperature of cooking process.

[5] showed that Paphia undulata contains higher protein contents, especially sarcoplasmic protein and myofibril protein, and it's a good source of protein, consisting of approximately $68.77 \%$ crud protein (dry weight basis). [28] reported that the protein content of all investigated oyster samples varied from $44.5 \%$ to $51.2 \%$ DW. There were no significant differences between species, locations and harvesting time.

In general, shellfish has higher protein contents than fin fish. Unlike vertebrates, raw shellfish muscle, in addition to myosin and other myofibrillar proteins, also contains the protein, paramyosin up to $19 \%(\mathrm{w} / \mathrm{w})$ [29].

Seafood is an excellent source of proteins and contains all essential amino acids and the proteins are easily digested; most proteins show a digestibility above 90\% [30] Shellfish proteins have PER values that are slightly above that of casein, the major milk protein [31]. Shellfish proteins provide all the essential amino acids for maintenance and growth of the human body [32]. Shellfish and other seafood are good sources of branched chain amino acids and taurine, which act beneficially on glucose metabolism and also blood pressure [33]. This mean that shellfish (Paphia undulata) which canned with different treatment in this study is considered a healthy and safety food for human consumption. 
Fat content was $8.49 \%, 9.23 \%$ and $14.96 \%$ in canned raw, canned smoked and canned cooked, respectively. Significant different $(\mathrm{p}<0.05)$ in fat content was found as a result of smoking process which cause decrease in moisture content therefore increasing in fat content canned smoked was noticed, while more increasing fat noticed in canned cooked Paphia undulata due to using corn oil in preparing seafood soup by Paphia undulata as a filling media of canned cooked. Heat treatments such as boiling and steaming, in general, have little impact on proximate composition of shellfish [34]. Shellfish items have low crude lipid contents, generally up to $2 \%(\mathrm{w} / \mathrm{w})$, the lipid contents of several shellfish have appreciable proportions of n-3 (omega-3) long-chain polyunsaturated fatty acids PUFAs [35] on the other hand the three treatments of canned shellfish Paphia undulata had Significant different $(\mathrm{p}<0.05)$ in content of ash and carbohydrates content were $(8.68 \%, 12.39 \%$ and $19.59 \%)$ and $(9.16 \%, 9.74 \%$, and $4.82 \%)$ in treatment canned raw, canned smoked and canned cooked respectively. Effect of heat treatment and ingredients which added to canned cooked noticed clearly in ash and carbohydrate content. [36], the raw red snow crab (body and leg muscles mix) consisted of $87.1 \%$ moisture, $10.6 \%$ protein, $0.3 \%$ lipid and $1.8 \%$ ash on $\mathrm{w} / \mathrm{w}$.

The contents of carbohydrate including dietary fiber in shellfish tissue are low. Carbohydrate varies from $1.3 \%$ in cooked lobster meat to $2 \%$ to $3 \%$ in oyster, and the green mussel [37]. Total calories value for canned shellfish (Paphia undulata) were $407.73,396.66$ and $397.12 \mathrm{Kcal} / 100 \mathrm{~g}$ of food and the percent protein derived calories were $18.07 \%, 17.34 \%, 15.26 \%$ for canned raw, canned smoked and canned cooked respectively. This mean the canned product rich in protein content with low total calories due to their low lipid and carbohydrate contents [2].

\subsection{3. pH}

$\mathrm{pH}$ value for canned shellfish Paphia undulata canned raw, canned smoked and canned cooked was 5.03, 4.53, and 5.47, respectively. the low value of $\mathrm{pH}$ in canned raw contribute to tomato sauce as a filling media which added to shellfish Paphia undulata but canned smoked this low $\mathrm{pH}$ as a result to smoking process and producing smoke compounds such as organic acids which cause reduction in $\mathrm{pH}$ value. Cooking process and present of ingredient which added to shellfish behind increase of $\mathrm{pH}$ in canned cooked shellfish Paphia undulata.

During smoking there is a reduction in water activity and in $\mathrm{pH}$ values as a result of heating, drying and deposition of some bactericidal compounds present in the smoke (phenol, derivatives, aldehydes and organic acids). These changes lead to the inactivation of enzymes and microorganisms responsible for deterioration, thus increasing the shelf life [38]. The $\mathrm{pH}$ value of fresh (Laubuka dadiburjori) fish was 6.8. Drop off $\mathrm{pH}$ value after canning process to 5.9 in canned fish [39]. The higher $\mathrm{pH}$ values observed in canned samples may by due to the formation and accumulation of some dibasic amino acid as a result of breakdown and proteolysis of proteins during heat treatment [40]. 


\subsubsection{Mineral Content}

Data in Table 3 showed that three treatments of canned shellfish Paphia undulata were rich in minerals and canned raw treatment was higher in $\mathrm{Ca}, \mathrm{Fe}, \mathrm{Zn}$, $\mathrm{Mg}$, and $\mathrm{Mn} 81.19,10.35,8.94,30.74$, and $0.85 \mathrm{mg} / 100 \mathrm{~g}$ respectively. While canned smoked had minerals content lower than canned raw 79.18, 8.83, 4.85, 23.55 and $0.63 \mathrm{mg} / 100 \mathrm{~g}$ respectively, at the same time canned cooked was the lowest in content minerals as $75.68,9.79,4.71,25.52$ and $0.61 \mathrm{mg} / 100 \mathrm{~g}$ respectively. This mean that a slightly reduction in minerals content noticed as a result of smoking and cooking process. The levels of manganese $(\mathrm{Mn})$ in the all samples ranged from 0.61 to $0.85 \mathrm{mg} / 100 \mathrm{~g}$. National Research Council of Canada (NRC) has recommended that the safe and adequate daily intake levels for manganese that range from 0.3 to $1 \mathrm{mg} /$ day for children up to 1 year, $1-2 \mathrm{mg} / \mathrm{day}$ for children up to age 10 , and $2-5 \mathrm{mg} /$ day for children 10 and older. While, the upper may intake level of manganese for children (1 - 3 years old) and males/females (19 - 70 years old) is 2 and $11 \mathrm{mg} /$ day respectively [25]. Daily intake of small amounts of manganese is needed for growth and good health in humans otherwise loss of manganese can cause nervous system problems.

The results in Table 3 showed that the iron ( $\mathrm{Fe}$ ) concentrations in all samples ranged from ( 8.83 to $10.35 \mathrm{mg} / 100 \mathrm{~g}$ ) so that fish is a major source of iron for adults and children. Iron deficiency causes anemia. The recommended dietary allowance of iron for infants and males/females 51 - 70 years is 11 and $8 \mathrm{mg} /$ day, respectively [25].

The data obtained that the zinc contents of samples were ranged from 4.71 to $8.94 \mathrm{mg} / 100 \mathrm{Zinc}$ is an essential element in human diet. Too little zinc can cause problems, however too much zinc is harmful to human health [24]. The upper tolerable intake level of zinc for children ( 1 - 3 years old) and males/females (19 - 70 years old) is 0.2 and $1 \mathrm{mg} /$ day, respectively [25]. Zinc helps in immune functions, healing of wounds, development of bones, and the cell membrane structure and functions. Zinc also may have a protective effect against atherosclerosis because of its anti-inflammatory and antioxidant functions [41]. Shellfish minerals contain microelements (sodium, potassium, calcium phosphate and magnesium, iron, selenium zinc and manganese [42]. Minerals are essential to human health, which cannot be synthesized by our body and have to be taken in from external environment [43]. Therefore, content of mineral element in fishery product is important for us to evaluate its nutritional quality [44].

Table 3. Minerals content (mg/100 g) of canned (Paphia undulata).

\begin{tabular}{cccc}
\hline Minerals mg/100g & Canned raw & Canned smoked & Canned cooked \\
\hline $\mathrm{Ca}$ & 81.19 & 79.18 & 75.68 \\
$\mathrm{Fe}$ & 10.35 & 8.83 & 9.79 \\
$\mathrm{Zn}$ & 8.94 & 4.85 & 4.71 \\
$\mathrm{Mg}$ & 30.74 & 23.55 & 25.52 \\
$\mathrm{Mn}$ & 0.85 & 0.63 & 0.61 \\
\hline
\end{tabular}




\subsection{Physicochemical and Sensorial Properties}

Colour: The colour of the product plays a pivotal role in the acceptability of the food product Results in Table 4 showed that lightness ( $L^{\star}$ ) had slightly different between all treatments canned shellfish Paphia undulata reduction on lightness and redness was noticed at the same time in all treatments of canned shellfish Paphia undulata Canned raw had highest value of lightness $\left(\mathrm{L}^{\star}\right)$, and redness $\left(a^{*}\right) 47.02$ and 12.76 respectively, compared with other treatments, and had lowest value of yellowness value 13.26 compared with canned smoked and canned cooked. Canned smoked had lowest value of lightness $\left(L^{*}\right) 43.46$ and highest value of yellowness $\left(b^{*}\right) 21.29$ as a result of smoking process which change the colour of shellfish to golden yellow, so that canned smoked had low value of redness $\left(a^{*}\right) 7.91$ compared with canned raw. Canned cooked had value of lightness $\left(\mathrm{L}^{\star}\right)$ was 44.36 , redness $\left(\mathrm{a}^{\star}\right) 6.59$ and yellowness 15.24 . It had lowest value of redness $\left(a^{*}\right)$ compared with other treatments due to the ingredient which added in cooking process. Higher decrease in redness $\mathrm{a}^{\star}$ values were reported for canned tuna with vegetables due to deposition of pigments migrated from vegetables. [45]. In muscle tissue, high temperature could induce the modifications of optical characteristics, which contributed to the changes in color [46]. These changes might be increased with prolonged cooking time. Also, increased lightness for cod fillets with increasing temperature and time, treated Atlantic mackerel had an increased L* with increasing temperature [47].

Texture Data in Table 4 reported texture of the three treatment of canned shellfish Paphia undulata as a hardness parameter that highest value noticed in canned smoked $123 \mathrm{~g}$ followed by canned raw with hardness value $109 \mathrm{~g}$ and canned cooked with hardness value $54 \mathrm{~g}$. The increase in the hardness upon thermal processing could be attributed to the heat treatment which reduces the water content of meat thereby improving the firmness of the meat [48]. And could be attributed to the loss of binding properties of connective tissue due to thermal denaturation of protein [49].

Sensory properties: According to sensory evaluation panelists accepted all treatments of canned shellfish Paphia undulata (Table 5). The degree of the preference of colour, odour, taste, texture and overall acceptability was very good and excellent. Slightly significant difference $(\mathrm{p}<0.05)$ was noticed between three treatments, data showed that all panelists prefer canned cooked than raw canned

Table 4. Colour and texture characteristics of canned Paphia undulata.

\begin{tabular}{cccc}
\hline Parameter & Canned raw & Canned smoked & Canned cooked \\
\hline$\underline{1-\text { Colour }}$ & & & \\
Lightness $\left(\mathrm{L}^{\star}\right)$ & 47.02 & 43.46 & 44.36 \\
Redness $\left(\mathrm{a}^{*}\right)$ & 12.76 & 7.91 & 6.59 \\
Yellowness $\left(\mathrm{b}^{*}\right)$ & 13.26 & 21.29 & 15.24 \\
2-Texture & 109 & 123 & 54 \\
Hardness $(\mathrm{g})$ & & & \\
\hline
\end{tabular}


Table 5. Sensory properties of canned Paphia undulata.

\begin{tabular}{cccc}
\hline Sensory properties & Canned raw & Canned smoked & Canned cooked \\
\hline Odour & $8.0 \pm 0.94^{\mathrm{b}}$ & $8.2 \pm 1.13^{\mathrm{b}}$ & $9.0 \pm 0.00^{\mathrm{a}}$ \\
Colour & $8.5 \pm 0.70^{\mathrm{a}}$ & $8.3 \pm 1.15^{\mathrm{a}}$ & $9.0 \pm 0.00^{\mathrm{a}}$ \\
Taste & $8.1 \pm 0.87^{\mathrm{b}}$ & $8.4 \pm 0.51^{\mathrm{b}}$ & $9.0 \pm 0.00^{\mathrm{a}}$ \\
Texture & $8.2 \pm 0.91^{\mathrm{ab}}$ & $8.0 \pm 0.94^{\mathrm{b}}$ & $8.9 \pm 0.31^{\mathrm{a}}$ \\
Appearance & $8.0 \pm 0.94^{\mathrm{b}}$ & $8.3 \pm 0.82^{\mathrm{ab}}$ & $8.9 \pm 0.31^{\mathrm{a}}$ \\
Overall Acceptability & $7.9 \pm 1.19^{\mathrm{b}}$ & $8.0 \pm 0.94^{\mathrm{b}}$ & $8.9 \pm 0.31^{\mathrm{a}}$ \\
\hline
\end{tabular}

Data as mean \pm SD. Means in the same column sharing the same letters are not significantly different at $\mathrm{P} \leq$ 0.05 level.

and canned smoked, degree of canned cooked was excellent, followed by canned smoked and the last one was canned raw. Smoking cause changes in the sensory characteristics such as flavor, texture, aroma and color.

In addition golden yellow, and cooked shellfish as seafood soup and canned with soup as a filling media resulted excellent taste, odour and colour.

\section{Conclusion}

The above data confirmed the successful production canned shellfish Paphia undulata as a new product and preservation of shellfish Paphia undulata by canning with different treatment as raw smoked and cooked. New product was safety, and healthy, and high protein and minerals content and with excellent sensory properties.

\section{Acknowledgements}

The author is thankful to Prof. Dr. Taha Abdelmottaleb El-Sesy Prof. of Meat and Fish Technology Research Department, Food Technology Research Institute, Agriculture Research Center, Cairo, Egypt, for his support and valuable advice during carrying out the work.

\section{Conflicts of Interest}

The author declares no conflicts of interest regarding the publication of this paper.

\section{References}

[1] Nybakken, J.W. (2001) Marine Biology: An Ecological Approach. 4th Edition, Addison-Wessley Publishing, Boston, 516.

[2] Nettleton, J.A. and Exler, J. (1992) Nutrients in Wild and Farmed Fish and Shellfish. Journal of Food Science, 57, 257-260. https://doi.org/10.1111/j.1365-2621.1992.tb05470.x

[3] Lorenzo, R.A., Tomac, A., Tapella, F., Yeannes, M.I. and Romero, M.C. (2021) Biochemical and Quality Parameters of Southern King Crab Meat after Transport Simulation and Re-Immersion. Food Control, 119, Article ID: 107480.

https://doi.org/10.1016/j.foodcont.2020.107480 
[4] Olatunde, O.O., Benjakul, S. and Vongkamjan, K. (2020) Cold Plasma Combined with Liposomal Ethanolic Coconut Husk Extract: A Potential Hurdle Technology for Shelf-Life Extension of Asian Sea Bass Slices Packaged under Modified Atmosphere. Innovative Food Science and Emerging Technologies, 65, Article ID: 102448. https://doi.org/10.1016/j.ifset.2020.102448

[5] He, X.Q., Cao, W.H., Zhao, Z.K. and Zhang, C.H. (2013) Analysis of Protein Composition and Antioxidant Activity of Hydrolysates from Paphia Undulate. Journal of Food and Nutrition Research, 1, 30-36.

[6] Wang, W. D. (2009) Breeding Condition Monitoring of Paphia Undulate from the East Valley Roller in Fujian Sea Area in China. Animals Breeding and Feed, 6, 17-21,

[7] World Health Organization (WHO) (2015) Food Safety. World Health Organization. http://www.who.int/mediacentre/factsheets/fs399/en/

[8] Leroi, F. (2014) Role of Bacteria in Seafood Products. In: Kim, S.K., Ed., Seafood Science: Advances in Chemistry Technology and Applications, CRC Press, Boca Raton, 397-432.

[9] Anon (1979) Oyster Culture. Central Marine Fisheries Research Institute, ICAR Golden Jubilee Publication, Cochin.

[10] Willmore, P., Etzel, M., Andress, E. and Ingham, B. (2015) Home Processing of Acid Foods in Atmospheric Steam and Boiling Water Canners. Food Protection Trends, 35, 150-160

[11] Harris, L.J. and Soule, K.E. (2017) Guidelines for Safe Canning of Acid Foods in a Steam Canner. University of California Agriculture and Natural Recourses, Davis. https://anrcatalog.ucanr.edu/pdf/8573.pdf https://doi.org/10.3733/ucanr.8573

[12] Skaljac, S., Petrovic, L., Tasic, T., Ikonic, P., Jokanovic, M., Tomovic, V., et al. (2014) Influence of Smoking in Traditional and Industrial Conditions on Polycyclic Aromatic Hydrocarbons Content in Dry Fermented Sausages (Petrovská klobása) from Serbia. Food Control, 40, 12-18.

https://doi.org/10.1016/j.foodcont.2013.11.024

[13] Balachandran, K.K. and Unnikrishnan Nair, T.S. (1976) Diversification in Canned Fishery Products: Canning of Clams and Mussels in Oil. Proceedings of Symposium on Fish Processing Industry in India, CFTRI, Mysore, 13-14 February 1975.

[14] Santipanichwing, R. and Suphantharika, M. (2007) Carotenoids as Colorants in Reduced-Fat Mayon-Naise Containing Spent Brewer's Yeast $\beta$-Glucan as a Fat Replacer. Food Hydrocolloids, 21, 565-574. https://doi.org/10.1016/j.foodhyd.2006.07.003

[15] Yuan, S. and Chang, S.K.C. (2007) Texture Profile of Tofu as Affected by Instron Parameters, Sample Preparation and Correlation of Instron Hardness and Springiness with Sensory Scores. Journal of Food Science, 72, 136-145.

https://doi.org/10.1111/j.1750-3841.2006.00263.x

[16] AOAC (2000) Official Methods of Analysis. 17th Edition, Association of Official Analytical Chemists, Gaithersburgh.

[17] Vitosevic, B., Samardzic, S., Antonijevic, V. and Jokovljevic, V. (2007) Heavy Metals in Some Imported Food Products and Their Potential Toxic Implications. Medicus, 8, 62-66.

[18] Meilgaard, M., Civille, G.V. and Carr, B.T. (1999) Sensory Evaluation Techniques. 3th Edition, CRC, Boca Raton, 8-12. https://doi.org/10.1201/9781003040729 
[19] He, J., Xuan, F.J., Shi, H., Xie, J.J., Wang, W., Wang, G.S. and Xu, W.J. (2017) Comparison of Nutritional Quality of Three Edible Tissues of the Wild-Caught and Pond-Reared Swimming Crab (Portunus trituberculatus) Females. LWT-Food Science and Technology, 75, 624-630. https://doi.org/10.1016/j.lwt.2016.10.014

[20] Tantratian, S. and Kaephen, K. (2020) Shelf-Life of Shucked Oyster In epigallocatechin-3-Gallate with Slightly Acidic Electrolyzed Water Washing under Refrigeration Temperature. LWT-Food Science and Technology, 118, Article ID: 108733. https://doi.org/10.1080/87559129609541074

[21] Demirezen, D. and Uruc, K. (2006) Comparative Study of Trace Elements in Certain Fish Meat and Meat Products. Meat Science, 74, 255-260. https://doi.org/10.1016/j.meatsci.2006.03.012

[22] Codex Committee on Food Additives and Contaminants (CCFAC) (2001) Comments Submitted on Draft Maximum Levels for Lead and Cadmium. Agenda 16c/16d, Joint FAO/ WHO Food Standards Programme, Thirty-Third Session, Hague, 12-16 March 2001.

[23] Commission of the European Communities (2001) Commission Regulation (EC) No. 221/2002 of 6 February 2002. Amending Regulation (EC) No. 466/2002 Setting Maximum Levels for Certain Contaminants in Foodstuffs, Brussels, 6 February 2002.

[24] Agency for Toxic Substances and Disease Registry (2004) Toxicological Profile for Zinc. Agency for Toxic Substances and Disease Registry, Division of Toxicology Clifton Road, Atlanta. http://www.atsdr.cdc.gov/toxprofiles/

[25] Institute of Medicine (2003) Dietary Reference Intakes: Applications in Dietary Planning. Subcommittee on Interpretation and Uses of Dietary Reference Intakes and the Standing Committee on the Scientific Evaluation of Dietary Reference Intakes. Institute of Medicine of the National Academies, the National Academies Press, Washington DC, 248.

[26] Hassan, I.M. (1988) Processing of Smoked Common Carp Fish and Its Relation to Some Chemical, Physical and Organoleptic Properties. Food Chemistry, 27, 9-106. https://doi.org/10.1016/0308-8146(88)90081-7

[27] Konosu, S., Yamaguchi, K. and Hayashi, T. (1978) Studies on Flavor Components in Boiled Crabs-1, Amino Acids and Related Compounds in the Extracts. Bulletin of the Japanese Society of Scientific Flsheries, 44, 505-510.

https://doi.org/10.2331/suisan.44.505

[28] Houcke, J ., Medina, I., Linssen, J. and Luten, J. (2016) Biochemical and Volatile Organic Compound Profile of European Flat Oyster (Ostrea edulis) and Pacific Cupped Oyster (Crassostrea gigas) Cultivated in the Eastern Scheldt and Lake Grevelingen, the Netherlands. Food Control, 68, 200-207.

https://doi.org/10.1016/j.foodcont.2016.03.044

[29] Venugopal, V. and Shahidi, F. (1996) Structure and Composition of Fish Muscle. Food Research International, 12, 175-179. https://doi.org/10.1080/87559129609541074

[30] Hamed, I., Ozogul, F., Ozogul, Y. and Regenstein, J.M. (2015) Marine Bioactive Compounds and Their Health Benefits: A Review. Comprehensive Reviews in Food Science and Food Safety, 14, 446-465. https://doi.org/10.1111/1541-4337.12136

[31] Venugopal, V. (2006) Seafood Processing: Adding Value through Quick Freezing, Retortable Packaging and Cook-Chilling. CRC Press, Boca Raton, 524.

[32] Friedman, K. (1996) Nutritive Value of Proteins from Different Food Sources a Review. Journal of Agricultural and Food Chemistry, 44, 6-29. 
https://doi.org/10.1021/jf9400167

[33] Elmadfa, I. and Meyer, A.L. (2017) Animal Proteins as Important Contributors to a Healthy Human Diet. Annual Review of Animal Biosciences, 5, 111-131.

https://doi.org/10.1146/annurev-animal-022516-022943

[34] Kreuzer, R. (1984) Cephalopods: Handling Processing and Products. Fisheries Technical Paper 254. Food and Agriculture Organization, Rome, 108.

[35] Berge, J.-P. and Barnathan, G. (2005) Fatty Acids from Lipids of Marine Organisms: Molecular Diversity; Role as Biomarkers; Biologically Active Compounds and Economical Aspects. Advances in Biochemical Engineering/Biotechnology, 96, 49-125. https://doi.org/10.1007/b135782

[36] Park, J.H., Min, J.G., Kim, T.J. and Kim, J. H. (2003) Composition of Food Components between Red-Tanner Crab, Chionoecetes Japonicus and Neodo-Daege, a New Species of Chionoecetes sp. Caught in the East Sea of Korea. Journal of the Korean Fisheries Society, 36, 62-64. https://doi.org/10.5657/kfas.2003.36.1.062

[37] Food and Agriculture Organization (FAO)/INFOODS (2016) Global Food Composition database for Fish and Shellfish. Version 10-uFiSh10.

http://www.fao.org/3/a-i6655e.pdf

[38] Lira, G.M., Barros Silva, K.W, Figueirêdo, B.C. and Bragagnolo, N. (2014) Impact of Smoking on the Lipid Fraction and Nutritional Value of Seabob Shrimp (Xiphopenaeus kroyeri, Heller, 1862). Food Science and Technology, 58, 183-187.

https://doi.org/10.1016/j.lwt.2014.02.057

[39] Sajib, A., Subrata, K., Hasan, S.R. and Riadul, H. (2015) Effect of Traditional Fish Processing Methods on the Proximate and Microbiological Characteristics of Laubuka dadiburjori during Storage at Room Temperature. Journal of Fisheries and Aquatic Science, 10, 232-243. https://doi.org/10.3923/jfas.2015.232.243

[40] Nimish, M.S., Jeya Shakila, R., Jeyasekaran, G. and Sukumar, D. (2010) Effect of Different Types of Heat Processing on Chemical Changes in Tuna. Journal of Food Science and Technology, 47, 174-181. https://doi.org/10.1007/s13197-010-0024-2

[41] Bao, B., Prasad, A.S., Beck, F.W., Fitzgerald, J.T., Shell, D., Bao, C.W., Singh, T. and Cardozo, L.J. (2010) Zinc Decreases C-Reactive Protein Lipid Peroxidation and Inflammatory Cytokines in Elderly Subjects: A Potential Implication of Zinc as an Atheroprotective Agent. The American Journal of Clinical Nutrition, 91, 1634-1641. https://doi.org/10.3945/ajen.2009.28836

[42] Dong, M.F. (2001) The Nutritional Value of Shellfish. Project A/PC-5, National Oceanic and Atmospheric Administration to Washington Sea Grant, University of Washington, Seattle, 1-4.

[43] Li, Y.F., Li, M.Y.,Wu, Z.Y., Huang,W.J. and Jiang, Z.Q. (2012) The Prelimilary Study on the Relation between Dietary Intakes with Mineral Status Adults. Acta Nutrimenta Sinica, 34, 250-256.

[44] Annie, M., Stephen, C. and Jean-Francois, H. (2000) Settlement Preferences and Early Migration of the Tropical Sea Cucumber Holoihuria scabra. Journal of Experimental Marine Biology and Ecology, 249, 89-110.

https://doi.org/10.1016/S0022-0981(00)00187-8

[45] Mohan, C.O., Remya, S., Ravishankar, C.N., Vijayan, P.K. and Srinivasa Gopal, T.K. (2014) Effect of Filling Ingredient on the Quality of Canned Yellowfin Tuna (Thunnus albacares). International Journal of Food Science \& Technology, 49, 1557-1564. https://doi.org/10.1111/ijfs.12452

[46] Hassoun, A., Cropotova, J., Rustad, T., Heia, K., Lindberg, S.-K. and Nilsen, H. 
(2020) Use of Spectroscopic Techniques for a Rapid and Non-Destructive Monitoring of Thermal Treatments and Storage Time of Sous-Vide Cooked Cod Fillets. Sensors, 20, 2410. https://doi.org/10.3390/s20082410

[47] Cropotova, J., Mozuraityte, R., Standal, I.B., Ojha, S., Rustad, T. and Tiwari, B. (2020) Influence of High-Pressure Processing on Quality Attributes of Haddock and Mackerel Minces during Frozen Storage and Fishcakes Prepared Thereof. Innovative Food Science and Emerging Technologies, 59, Article ID: 102236. https://doi.org/10.1016/j.ifset.2019.102236

[48] Tanaka, M., Nagashima, Y. and Taguchi, T. (1985) Quality Comparison of Canned Mackerel with Equal Lethality. Bulletin of the Japanese Society of Scientific Fisheries, 51, 1737-1742. https://doi.org/10.2331/suisan.51.1737

[49] Dunajski, E. (1979) Texture of Fish Muscle. Journal of Texture Studies, 10, 301-318. https://doi.org/10.1111/j.1745-4603.1980.tb00862.x 